\title{
Persistent organic pollutants in four bivalve species from Svalbard waters
} \author{
William L. Locke $\mathrm{V}^{\mathrm{d}}$, Geir W. Gabrielsen ${ }^{\mathrm{a}}$ \\ a Norwegian Polar Institute, Fram Centre, N-9296 Tromsø, Norway \\ ${ }^{\mathrm{b}}$ Alfred Wegener Institute for Polar and Marine Research, Am Handelshafen 12, 27570 Bremerhaven, Germany \\ ${ }^{\mathrm{c}}$ Norwegian Institute for Air Research, Fram Centre, N-9296 Tromsø, Norway \\ d Bates College, Department of Biology, Lewiston, ME 04240, USA \\ e Akvaplan-niva, Fram Centre, N-9296 Tromsø, Norway
}

Ireen Vieweg ${ }^{\mathrm{a}, *}$, Haakon Hop ${ }^{\mathrm{a}}$, Thomas Brey ${ }^{\mathrm{b}}$, Sandra Huber ${ }^{\mathrm{c}}$, William G. Ambrose Jr. ${ }^{\mathrm{d}, \mathrm{e}}$,

\section{A R T I C L E I N F O}

\section{Article history:}

Received 20 May 2011

Received in revised form

5 October 2011

Accepted 12 October 2011

\section{Keywords:}

Arctic bivalve

Persistent organic pollutant

Kongsfjorden

Liefdefjorden

Bivalve age

\begin{abstract}
A B S T R A C T
Organochlorine compounds (OC) were determined in Arctic bivalves (Mya truncata, Serripes groenlandicus, Hiatella arctica and Chlamys islandica) from Svalbard with regard to differences in geographic location, species and variations related to their size and age. Higher chlorinated polychlorinated biphenyls (PCB 101-PCB 194), chlordanes and $\alpha$-hexachlorocyclohexane $(\alpha-\mathrm{HCH})$ were consistently detected in the bivalves and PCBs dominated the OC load in the organisms. OC concentrations were highest in Mya truncata and the lowest in Serripes groenlandicus. Species-specific OC levels were likely related to differences in the species' food source, as indicated by the $\delta^{13} \mathrm{C}$ results, rather than size and age. Higher $O C$ concentrations were observed in bivalves from Kongsfjorden compared to the northern sampling locations Liefdefjorden and Sjuøyane. The spatial differences might be related to different water masses influencing Kongsfjorden (Atlantic) and the northern locations (Arctic), with differing phytoplankton bloom situations.
\end{abstract}

(c) 2011 Elsevier Ltd. All rights reserved.

\section{Introduction}

Environmental contaminants reflect the impact of human activities on the environment, and assessments of these substances provide the opportunity to evaluate the risk of currently or formerly used substances. Organochlorine compounds (OC) such as organochlorine pesticides (hexachlorocyclohexanes [HCH], chlordanes, dichlorodiphenyltrichloroethane [DDT]) and industrial chemicals (hexachlorobenzene $[\mathrm{HCB}]$, polychlorinated biphenyls [PCBs]) have been defined as persistent organic pollutants (POPs) by the Stockholm Convention on Persistent Organic Pollutants in 2001 (Program U.N.E., 2001). These 'legacy POPs' have subsequently been banned or restricted, although they still persist in the environment and in marine biota due to their persistence against biological and physical degradation processes and their bioaccumulation in the adipose tissue of animals. Concentrations of legacy POPs have been found to decline during the last decade in

\footnotetext{
* Corresponding author.

E-mail addresses: ireen.vieweg@npolar.no (I. Vieweg), haakon.hop@npolar.no (H. Hop), Thomas.Brey@awi.de (T. Brey), sandra.huber@nilu.no (S. Huber),wambrose@ bates.edu (W.G. Ambrose), wlocke@bates.edu (W.L. Locke V), geir.wing.gabrielsen@ npolar.no (G.W. Gabrielsen).
}

the Arctic (Bustnes et al., 2010; Henriksen et al., 2001), but nevertheless continuous biomonitoring is important in order to understand the degradation and fate of these OCs in the Arctic environment (AMAP, 2004).

Several OC assessments have been conducted for Arctic biota during the last decades with special emphasis on OC load in organisms of higher trophic level and on the dynamics of OCs within food webs due to biomagnifications (AMAP, 1998, 2004). Few studies have focused on benthic primary consumers exclusively (Angot, 2009; Doidge et al., 1993; Fisk et al., 2003; Hop et al., 2001; Kjolholt and Hansen, 1986; Tessmann, 2008), although they do define the baseline $\mathrm{OC}$ levels in marine food webs. Lower trophic level organisms generally exhibit relatively low OC concentrations (Borgå et al., 2001), which are mostly influenced by the OC concentrations of sea water (dissolved fraction) and in their food (e.g. phytoplankton), as well as by the rate of OC elimination from their bodies. Several studies, however, have highlighted the importance of biological factors (e.g. lipid content, habitat, feeding strategy, trophic level and seasonality) for the OC dynamics in zooplankton (Borgå et al., 2004; Hallanger et al., 2011a, 2011b; Hargrave et al., 2000) and benthic invertebrates (Fisk et al., 2003). In Arctic bivalves from the Canadian and European Arctic, the OC load is predominated by PCBs, though other legacy POPs are also present (Doidge et al., 1993; Fisk et al., 2003; Rabieh et al., 
2008; Tessmann, 2008). Active military sites have been identified as point sources for PCBs in bottom-dwelling organisms in the Canadian Arctic (Bright et al., 1995; Kuzyk et al., 2005). In Svalbard, town settlements such as Barentsburg have also been indicated as PCB point sources for the macro-benthos (Evenset and Christensen, 2009; Hop et al., 2001), whereas the main source of PCBs is attributed to long-range transport (Wania and Mackay, 1993).

Pronounced changes in sea ice cover, ocean currents, and atmospheric circulation are predicted for the Arctic (IPCC, 2007). These changes may affect the long-range transport of contaminants as well as the balance between deposition and release of OCs from Arctic waters and sediments (Macdonald et al., 2003). The present study was part of the COPOL (Contaminants in Polar Regions) project, which aimed to understand how changes in the OC patterns of Arctic animals could be attributed to different water masses (i.e. Atlantic and Arctic) influencing the Arctic marine ecosystem. The Svalbard archipelago is typical in this respect, as it is affected by both the warm, saline West Spitsbergen Current (WSC) and the cold, relatively fresh East Spitsbergen Current (ESC) (Svendsen et al., 2002). Kongsfjorden (north-west coast of Svalbard) is strongly influenced by both the warm Atlantic and cold Arctic water influx into the fjord (Hop et al., 2002), whereas the north coast of Svalbard (i.e. Liefdefjorden and Sjuøyane) is exposed to Arctic water masses predominantly. Our study analyzed organochlorine levels in four bivalve species from Kongsfjorden (Atlantic influence) and Liefdefjorden (Arctic influence). Additionally, Sjuøyane was included in the analysis as a site representing 'truly' Arctic conditions. Our main objective was to examine whether organochlorine concentrations in bivalves depend on the geographical location, species, food source, tropic position or size and age.

\section{Materials and methods}

\subsection{Sampling}

Bivalve samples of Mya truncata, Serripes groenlandicus, Hiatella arctica and Chlamys islandica were collected by SCUBA divers in July 2009 in Svalbard. The sampling effort was focused on: Kongsfjorden-Forlandsundet (hereafter Kongsfjorden; $\left.78^{\circ} 54.2^{\prime} \mathrm{N}, 11^{\circ} 04.8^{\prime} \mathrm{E}\right)$, Liefdefjorden ( $\left.79^{\circ} 39^{\prime} \mathrm{N}, 13^{\circ} 27.1^{\prime} \mathrm{E}\right)$ and Sjuøyane (80 $38^{\prime} \mathrm{N}, 20^{\circ} 47.9^{\prime} \mathrm{E}$ ) (Fig. 1). The bivalve samples were taken from 13 sites within diving depths in Kongsfjorden (9.4-32.9 m), Liefdefjorden (14-34.5 m) and Sjuøyane (14.3-14.7 m). In Sjuøyane, only M. truncata was found. All animals were wrapped separately in aluminium foil, put in zip-lock bags and frozen at $-80^{\circ} \mathrm{C}$ until analyses.

Shell length (SL) of each individual was measured with a digital calliper $( \pm 0.1 \mathrm{~mm})$ and used to determine size-ranges for each species and location. From these size-ranges, subsets of animals representing the whole size-spectrum were selected for further analysis. The bivalve tissue was removed and homogenized with a blender. In the case of small-sized specimens (particularly $\mathrm{H}$. arctica), the tissue of several individuals with similar SL had to be pooled in order to obtain sufficient tissue biomass for all analyses.

Oceanographic observations, carried out at the time of sampling, indicated the dominance of Atlantic water (temperature, $T>3{ }^{\circ} \mathrm{C}$ ) in Kongsfjorden and the adjacent continental shelf. In Liefdefjorden, Atlantic Water occupied the middle layer of the water column, while Arctic-type water was detected in the bottom layer. Accordingly, Liefdefjorden $\left(T=1-3{ }^{\circ} \mathrm{C}\right)$ was less influenced by Atlantic water masses than Kongsfjorden. Polar surface water $\left(T<0{ }^{\circ} \mathrm{C}\right)$, which is formed through interaction between Atlantic Water and melting sea ice (Rudels et al., 2000), dominated the Sjuøyane site. Furthermore, during winter 2008-2009 Kongsfjorden was covered by sea ice rather briefly, while Liefdefjorden remained ice covered until the middle of July, just 2.5 weeks before our sampling.

\subsection{Analysis of stable isotopes}

Representative samples of the four bivalve species from the three locations were selected for analysis of stable isotope ratios $\left(\delta^{13} \mathrm{C}\right.$ and $\left.\delta^{15} \mathrm{~N}\right)$ at the Institute for Energy Technology (IFE) in Kjeller, Norway. Approximately $0.5 \mathrm{~g}$ (wet weight [ww]) of the homogenized bivalve tissue was dried at $60-70{ }^{\circ} \mathrm{C}$ for $48 \mathrm{~h}$ and then crushed to powder with mortar and ceramic pestle. Further processing was performed according to Søreide et al. (2006b). The samples were combusted in a Eurovector (EA 3028) element analyzer and quantified with a Nu-Horizon, Isotope Ratio Mass Spectrometer from Nu-Instruments. Quality accuracy of the analyses was ensured by replicate analyses of internal standards (IFE trout) and international standards

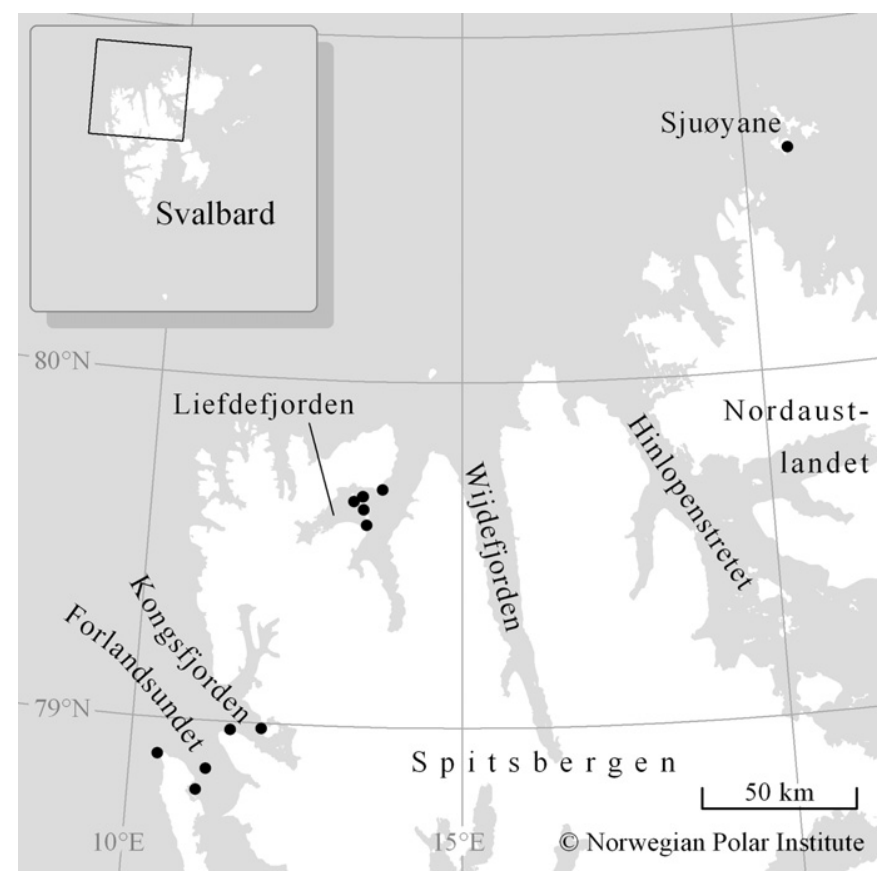

Fig. 1. Sampling locations in north-west Svalbard. Black dots indicate the dive locations in Kongsfjorden, Liefdefjorden and Sjuøyane, 2009 (source: Anders Skoglund, NPI).

(IAEA-N-1, IAEA-N-2 for $\delta^{15} \mathrm{~N}$ and USGS-24 for $\delta^{13} \mathrm{C}$ ). Replicate measurements of IFE trout were generally run for every 10 -samples, indicating measurement errors of $\pm 0.12 \%$ and $\pm 0.07 \%$ for $\delta^{15} \mathrm{~N}$ and $\delta^{13} \mathrm{C}$, respectively. The isotopic fractions for $\delta^{15} \mathrm{~N}$ and $\delta^{13} \mathrm{C}$ were defined against atmospheric nitrogen and Vienna Peedee Belemnite, respectively. Values for $\delta^{13} \mathrm{C}, \delta^{15} \mathrm{~N}$ and trophic levels were calculated according to Renaud et al. (2011).

\subsection{Age determination}

The age of M. truncata and H. arctica was inferred from the annual growth band pattern visible in the chondrophore and the hinge plate after preparation. One valve was embedded in epoxy resin and cross-sectioned with a low speed diamond saw through the umbo and along the line of maximum shell growth. The cross-section was polished with a grinder-polisher and subsequently etched with the caustic Mutvei's solution (Schöne et al., 2005). The age of S. groenlandicus was inferred from the external growth bands on the shell, which have been verified as annual growth checks (Ambrose et al., 2006). In C. islandica, the ring structure of the shell ligament was used for age determination (Johannessen, 1973). The age determination was performed by an experienced technician at the laboratory of W. G. Ambrose Jr., Bates College, Lewiston, Maine (USA).

The relationship between bivalve size (SL) and age (years) was modelled by the von Bertalanffy growth function (von Bertalanffy, 1957):

$S_{t}=S_{\infty} \cdot\left(1-e^{\wedge}\left(-k \cdot\left(t-t_{0}\right)\right)\right)$

where $S_{\infty}=$ maximum, asymptotic size, $k=$ growth constant, $t=$ age, and $t_{0}=$ age when size, $S=0$. The model was fitted to the size-at-age data by means of a nonlinear iterative fitting routine implemented in Microsoft Excel (Brey, 2001).

\subsection{Organochlorine analysis}

Analysis of OCs was carried out at the Norwegian Institute for Air Research (Tromsø, Norway). The bivalve samples were extracted and analyzed for polychlorinated biphenyls (PCBs) and organochlorine pesticides, according to Herzke et al. (2009), but with some modifications: the homogenized bivalve material was extracted with a cyclohexane-acetone solvent mixture (3:1) and only two purification methods were applied successively; Gel Permeation Chromatography (GPC) system and a clean-up on florisil-columns. An additional GPC step was necessary in order to purify the extracts from a thermoplastic elastomer (TPE)-polymer (see Supplementary data for details). The percentage of extractable organic matter (EOM) in the samples was determined gravimetrically (\% EOM) in an aliquot from the original extract right after the cold-column extraction. The proportion of EOM in the analytical sample is hereafter presented as the lipid content of the samples, as has been done in other studies (Fisk et al., 2003; Hallanger et al., 2011a). 
Instrumental analysis was carried out on an Agilent 7890A gas chromatograph (GC) with autosampler, coupled to a $5975 \mathrm{C}$ mass spectrometer (both Agilent Technologies) with helium as carrier gas. The injector was run in splitless mode $\left(T=250^{\circ} \mathrm{C}\right)$ with $1 \mu \mathrm{l}$ injection volume. Temperature programmed chromatographic separation was performed on a DB-5 MS column $(30 \mathrm{~m} \times 0.25 \mathrm{~mm} \times 0.25 \mu \mathrm{m}$, Agilent Technologies). The GC-program included: $70{ }^{\circ} \mathrm{C}(3 \mathrm{~min}), 15^{\circ} \mathrm{C} \min ^{-1}$ to $180{ }^{\circ} \mathrm{C}, 5^{\circ} \mathrm{C} \mathrm{min}-1$ to $280^{\circ} \mathrm{C}, 30^{\circ} \mathrm{C} \mathrm{min}^{-1}$ to $320^{\circ} \mathrm{C}$ and held for $5 \mathrm{~min}$. Temperatures of transferline, ion source and quadrupole were set to $300{ }^{\circ} \mathrm{C}, 160^{\circ} \mathrm{C}$ and $150{ }^{\circ} \mathrm{C}$, respectively. Negative chemical ionization with methane as reaction gas was applied for monitoring of ions in selected ion monitoring mode. Final quantification of the results was performed by the internal standard method together with a one-point calibration.

Quality assurance of the analyses was performed by including laboratory blanks and two certified standard references materials used in sequence (PCBs and pesticides: SRM 1588b cod liver oil and SRM 1945 in whale blubber, both from The National Institute of Standards and Technology, Gaithersburg, USA). Limit of detection (LOD) was defined as $3 \times$ signal noise for the analyzed matrix or blank value. The LODs ranged from $0.05 \mathrm{ng} \mathrm{g}^{-1}$ to $47.7 \mathrm{ng} \mathrm{g}^{-1}$ lipid weight (lw), depending on the analyte extracted. Due to blank contamination, the LOD for HCB was relatively high (47.7 $\mathrm{ng} \mathrm{g}^{-1} \mathrm{lw}$ ) compared to previous analyses (Angot, 2009).

\subsection{Data processing}

Total OC concentration in the bivalves was summarized $\left(\sum\right)$ in the groups $\sum$ CHLOR and $\sum$ PCB, which were represented by the mean concentration of al compounds included, whereas $\mathrm{HCB}$ and $\alpha-\mathrm{HCH}$ represent single OC groups. $\sum$ CHLOR consists of oxy-, cis-, and trans-chlordane, trans-, and cis-nonachlor and heptachlorepoxide, whereas $\sum$ PCB includes all higher chlorinated PCB congeners analyzed (PCB 101-194). Certain OCs (Mirex, heptachlor, $\beta$-HCH, PCB 99, PCB 123 PCB 189) were detected in $<20 \%$ of all samples in each species and not considered here. OCs found in $>20 \%$ of all samples in at least one species were included in the data set for the respective species (HCB, heptachlorepoxide, PCB 101, PCB 183). The reference point of $20 \%$ is based on previous studies of OCs in organisms of lower trophic levels (Hallanger et al., 2011b,c).

Principal component analysis (PCA, CANOCO for Windows) was used to assess the covariation in OC concentrations among samples, and to investigate the effect of explanatory variables (species, size, age, location) on the observed OC pattern. Data from Sjuøyane and those referring to the compounds HCB, PCB 101 and heptachlorepoxide were excluded from PCA because they did not include all four bivalve species. The explanatory variables were included as passive variables in the analysis and did not influence the sample distribution in the ordination space. Prior to statistical analysis, a generalized linear model (GLM) with binomial error distribution was used in order to evaluate if it was appropriate to exclude the samples with OC concentrations < LOD (non-detects) from statistical analyses. The model determined whether the probability of OC levels being above the LOD varied significantly among the bivalve species and locations. Furthermore, the OC concentrations were $\log _{\mathrm{e}}$ transformed in order to obtain constant variances and normal distributions of the residuals (assessed by diagnostic plots, such as quantile-quantile plot and Shapiro-Wilk's W test). Patterns detected in the PCA-plot were tested for significance by two-way analysis of variance (ANOVA; site $\times$ species) and subsequent post hoc test on differences between means (Tukey's honestly significant difference [HSD] with significance level $p<0.05$ ). The PCA-plot indicated no correlation between size (age) and OC levels, so linear regression was used in order to assess the relationship between these factors.

\section{Results}

\subsection{OC pattern in four arctic bivalves}

The mean OC concentrations ranged from 0.1 to $79.0 \mathrm{ng} \mathrm{g}^{-1} \mathrm{lw}$ for all bivalves and locations (Table 3). Concentrations are lipid normalized due to significant EOM differences among the four species (ANOVA: $F_{3.79}=25.27, p<0.001$ ), with significantly lower values in $M$. truncata (Table 3 ).

Probability of OC levels to be above the LOD did not differ among species (for $\sum$ CHLOR, $\alpha-\mathrm{HCH}$ ) or location (for $\sum$ PCB, $\sum$ CHLOR, $\alpha$ $\mathrm{HCH}$ ), thus justifying the exclusion of non-detects from statistical analysis. A significant difference, however, was found for $\sum \mathrm{PCB}$ among species $\left(\chi_{3}^{2}=13.257, p=0.004\right)$ due to the higher amount of non-detects in S. groenlandicus compared to C. islandica $(z=2.13$, $\mathrm{df}=79, p=0.034$ ), while all other bivalve species pairs did not differ significantly. This was in accordance with consistently lower OC levels found in S. groenlandicus compared to the other species.

Specific groups showed a distinct pattern of relative share in total $\sum O C$ concentration (Fig. 4). $\sum$ PCB was the predominant OC group, accounting for $70-82 \%$ of the total $\sum O C$ (Table 3 ). HCB was only detected in $M$. truncata from Kongsfjorden, where it showed the highest concentration of all OCs analyzed (mean $61.08 \pm 1.33$ [SD] $\mathrm{ng} \mathrm{g}^{-1} \mathrm{lw}$ ). Of all PCB congeners analyzed, PCB 118 and PCB 138 had the highest concentrations (mean $14.9 \pm 9.6[\mathrm{SD}] \mathrm{ng} \mathrm{g}^{-1} \mathrm{lw}$; $14.2 \pm 8.2 \mathrm{ng} \mathrm{g}^{-1} \mathrm{lw}$, respectively) and accounted for $45 \%$ of $\sum \mathrm{PCB}$ (23\% and $22 \%$, respectively). $\sum$ CHLOR constituted $13-21 \%$ of the $\sum O C$ concentration in the bivalves, and cis-nonachlor was the predominant compound observed in this OC group accounting for $46 \%$ of $\sum$ CHLOR. The isomer $\alpha-\mathrm{HCH}$ represented $5-9 \%$ of $\sum \mathrm{OC}$ in the bivalves (Fig. 4).

The influence of species, location, size and age on the OC pattern in bivalves was explored visually by plotting Principle Component (PC) 1 and 2, which respectively explained $63.3 \%$ and $11.3 \%$ of the variation in OC concentration among the samples (Fig. 5). Samples with highest concentrations were distributed most negatively (i.e. towards the left) along the PC1 axis and samples with lowest concentrations segregated most positively along $\mathrm{PC} 1$, showing that PC1 separated the samples based on their OC concentrations. The different distribution of the four bivalve species along PC1 and PC2 and the two locations along PC1 in the PCA-plot indicates that these variables can explain the OC pattern found. This was not the case for the variable size, co-occurring with the largest species C. islandica, and age (close to origo). This coincides with the finding that $\sum$ PCB and $\sum$ CHLOR levels did not change significantly neither with bivalve size nor age. Although significant relationships were found between the $\alpha-\mathrm{HCH}$ levels and the variables size and age $\left(r^{2}=0.13, p<0.01 ; r^{2}=0.11, p<0.01\right.$, respectively), scatter plots revealed that only the variability of $\alpha-\mathrm{HCH}$ changed (decreased and increased, respectively) with increasing size and age. Finally, twoway ANOVA showed no interaction between the variable species and location for all OC groups (in all cases $p>0.20$ ), indicating that it is appropriate to assess the influence of these factors separately on the OC pattern.

Mean total concentration of all detected compounds ( $\left.\sum \mathrm{OC}\right)$ varied among the four species sampled in Kongsfjorden and Liefdefjorden. The highest $\sum O C$ concentration was detected in M. truncata $\left(117.0 \pm 77.5 \mathrm{ng} \mathrm{g}^{-1} \mathrm{lw}\right)$ and the lowest in S. groenlandicus $\left(53.0 \pm 44.3 \mathrm{ng} \mathrm{g}^{-1} \mathrm{lw}\right)$, whereas H. arctica and C. islandica exhibited similar, intermediate $\sum$ OC levels $(74.9 \pm 35.7$ and $73.6 \pm 29.0$ $n \mathrm{ng}^{-1} \mathrm{lw}$, respectively). Levels of $\sum$ CHLOR and $\alpha$-HCH differed significantly among the species (ANOVA: $F_{3.79}=16.298, p<0.001$; $F_{3.57}=56.930, p<0.001$, respectively, Fig. 6 ). $\sum$ CHLOR concentrations were significantly lower in $S$. groenlandicus compared to the other species (Tukey HSD: in all cases $p<0.001$ ). Mya truncata and $H$. arctica had significantly higher $\alpha-\mathrm{HCH}$ levels compared to the other bivalves (Tukey HSD: in all cases $p<0.001$ ), whereas the $\alpha$ $\mathrm{HCH}$ level was significantly higher in $M$. truncata than in $H$. arctica (Tukey HSD: $p=0.006$ ).

Different OC levels were found in the same bivalve species between Kongsfjorden and Liefdefjorden (Fig. 6). $\sum$ PCB was significantly (ANOVA: $F_{1.70}=4.417, p=0.039$ ) higher in Kongsfjorden $\left(66.8 \pm 42.9 \mathrm{ng} \mathrm{g}^{-1} \mathrm{lw}\right)$ than in Liefdefjorden $(51.6 \pm 39.9$ $\mathrm{ng} \mathrm{g}^{-1} \mathrm{lw}$ ), as was $\sum$ CHLOR (ANOVA: $F_{1.79}=9.136, p=0.003$ ), $\left(16.2 \pm 7.7 \mathrm{ng} \mathrm{g}^{-1} \mathrm{lw}\right.$ versus $\left.12.7 \pm 5.9 \mathrm{ng} \mathrm{g}^{-1} \mathrm{lw}\right)$. Since only M. truncata was collected from Sjuøyane, no statistical comparison was done with this location.

\subsection{Size and age}

The bivalve sizes included in our study did represent the sizespectrum of the four bivalves, that could be retrieved by divers in the sampling areas (Table 2). The size was used as indicator for bivalve age. This assumption was confirmed for $M$. truncata $\left(r^{2}=0.61, p<0.05\right)$, S. groenlandicus $\left(r^{2}=0.88, p<0.05\right)$ and 
Table 1

Stable isotopes $\left(\delta^{13} \mathrm{C}, \delta^{15} \mathrm{~N}\right)$ in samples $(n)$ of four bivalve species from Svalbard shown as mean $\pm \mathrm{SE}(\%$ o $)$. Trophic levels $(\mathrm{TL})$ are calculated by TL $=\left(\delta^{15} \mathrm{~N}_{\text {consumer }}-\delta^{15} \mathrm{~N}_{\mathrm{POM}} /\right.$ $3.4)+1$.

\begin{tabular}{|c|c|c|c|c|c|c|c|}
\hline \multirow[t]{2}{*}{ Taxa } & \multirow[t]{2}{*}{ Location } & \multirow[t]{2}{*}{$n$} & \multicolumn{2}{|l|}{$\delta^{13} \mathrm{C}$} & \multicolumn{3}{|l|}{$\delta^{15} \mathrm{~N}$} \\
\hline & & & Mean \pm SD & Range & Mean \pm SD & Range & $\mathrm{TL}$ \\
\hline \multirow[t]{4}{*}{ Mya truncata } & Kongsfjorden & 5 & $-19.8 \pm 0.4$ & $(-20.4)-(-19.4)$ & $6.8 \pm 0.5$ & $6.2-7.5$ & 2.0 \\
\hline & Liefdefjorden & 5 & $-19.9 \pm 0.9$ & $(-21.0)-(-19.1)$ & $6.6 \pm 0.2$ & $6.3-6.8$ & 1.9 \\
\hline & Sjuøyane & 4 & $-20.1 \pm 0.4$ & $(-20.6)-(-19.8)$ & $7.1 \pm 0.4$ & $6.6-7.6$ & 2.1 \\
\hline & All locations & 14 & $-20.0 \pm 0.6$ & $(-21.0)-(-19.1)$ & $6.8 \pm 0.4$ & $6.2-7.6$ & 2.0 \\
\hline \multirow[t]{3}{*}{ Serripes groenlandica } & Kongsfjorden & 5 & $-20.8 \pm 0.5$ & $(-21.5)-(-20.4)$ & $6.9 \pm 0.3$ & $6.4-7.3$ & 2.0 \\
\hline & Liefdefjorden & 5 & $-21.5 \pm 0.8$ & $(-22.2)-(-20.2)$ & $6.7 \pm 0.6$ & $6.1-7.5$ & 1.9 \\
\hline & All locations & 10 & $-21.2 \pm 0.7$ & $(-22.2)-(-20.4)$ & $6.8 \pm 0.5$ & $6.1-7.5$ & 2.0 \\
\hline \multirow[t]{3}{*}{ Hiatella arctica } & Kongsfjorden & 3 & $-20.3 \pm 0.4$ & $(-20.7)-(-19.9)$ & $6.9 \pm 0.4$ & $6.4-7.2$ & 2.0 \\
\hline & Liefdefjorden & 3 & $-21.3 \pm 0.3$ & $(-21.7)-(-21.2)$ & $7.0 \pm 0.3$ & $6.7-7.2$ & 2.0 \\
\hline & All locations & 6 & $-20.8 \pm 0.7$ & $(-21.7)-(-19.9)$ & $6.9 \pm 0.3$ & $6.4-7.2$ & 2.0 \\
\hline \multirow[t]{3}{*}{ Chlamys islandica } & Kongsfjorden & 5 & $-21.1 \pm 0.2$ & $(-21.5)-(-20.9)$ & $8.1 \pm 0.3$ & $7.6-8.3$ & 2.3 \\
\hline & Liefdefjorden & 5 & $-22.0 \pm 0.2$ & $(-22.2)-(-21.7)$ & $7.5 \pm 0.4$ & $6.8-8.0$ & 2.2 \\
\hline & All locations & 10 & $-21.6 \pm 0.5$ & $(-22.2)-(-20.9)$ & $7.8 \pm 0.5$ & $7.6-8.3$ & 2.3 \\
\hline
\end{tabular}

C. islandica $\left(r^{2}=0.66, p<0.05\right)$ (Bertalanffy growth model; Fig. 3 ). In $H$. arctica, however, size was not significantly related to age $\left(r^{2}=0.01\right.$, Fig. 3$)$. Therefore, the a priori pooling of $H$. arctica specimens with similar SL in one analytical sample caused these samples to represent a very wide age-range (8-34 years). Accordingly, mean age per sample of $H$. arctica was not used in the multivariate analyses.

\subsection{Stable isotopes}

The $\delta^{15} \mathrm{~N}$-values differed significantly among the four bivalve species (ANOVA: $F_{3.31}=14.298, p<0.001$ ); $\delta^{15} \mathrm{~N}$ was significantly higher in C. islandica than in the other species (Tukey HSD: in all cases $p<0.002$ ) (Table 1; Fig. 2). Across all species, there was no significant correlation between $\delta^{15} \mathrm{~N}$ and OC levels (linear regressions: $0.65<p<0.76$ ). The $\delta^{13} \mathrm{C}$-values also showed significant differences among species (ANOVA: $F_{3.31}=16.609, p<0.001$ ) (Table 1), with significantly higher values in M. truncata (Tukey HSD: in all cases $p<0.01$ ). Furthermore, $\delta^{13} \mathrm{C}$-values in bivalves from Kongsfjorden $(-20.5 \% \pm 0.15 \%$ ) were significantly higher (ANOVA: $\left.F_{1.31}=10.845, p=0.002\right)$, than in Liefdefjorden $(-21.2 \% \pm 0.24 \%)$. No significant correlation between $\delta^{13} \mathrm{C}$ and OC levels was detected in the four species for $\sum$ PCB (linear regressions: $0.08<p<0.8$ ) and $\alpha-\mathrm{HCH}(0.19<p<0.63)$. Significant correlations were found for $\sum$ CHLOR $\left(r^{2}=0.48, p=0.03\left[\right.\right.$ M. truncata]; $r^{2}=0.70, p=0.04$ [H. arctica]), although scatter plots revealed that the variability of $\sum$ CHLOR decreased with increasing $\delta^{13} \mathrm{C}$.

Table 2

Mean $( \pm \mathrm{SD})$ and range of shell length $(\mathrm{mm})$ for the four bivalves at locations in Svalbard presented together with the number of samples $(n)$ for the species and locations.

\begin{tabular}{llrll}
\hline Taxa & Location & $n$ & \multicolumn{2}{l}{ Shell length $(\mathrm{SL})$} \\
\cline { 4 - 5 } & & & Mean \pm SD & Range \\
\hline Mya truncata & Kongsfjorden & 11 & $28.6 \pm 9.5$ & $12.3-44.8$ \\
& Liefdefjorden & 10 & $33.0 \pm 8.2$ & $19.4-44.8$ \\
& Sjuøyane & 5 & $16.9 \pm 4.7$ & $10.4-28.4$ \\
Serripes groenlandicus & All locations & 26 & $25.9 \pm 10.5$ & $10.4-44.8$ \\
& Kongsfjorden & 12 & $21.5 \pm 3.6$ & $15.4-64.4$ \\
& Liefdefjorden & 11 & $32.3 \pm 15.4$ & $17.1-66.6$ \\
Hiatella arctica & All locations & 23 & $27.8 \pm 12.9$ & $15.4-66.6$ \\
& Kongsfjorden & 9 & $17.1 \pm 2.7$ & $9.3-21.9$ \\
& Liefdefjorden & 6 & $15.1 \pm 2.8$ & $9.4-19.9$ \\
Chlamys islandica & All locations & 15 & $16.2 \pm 2.9$ & $9.3-21.9$ \\
& Kongsfjorden & 12 & $70.4 \pm 23.9$ & $49.7-96.7$ \\
& Liefdefjorden & 13 & $62.6 \pm 13.6$ & $42.3-88.1$ \\
& All locations & 25 & $66.0 \pm 15.0$ & $42.3-96.7$ \\
\hline
\end{tabular}

\section{Discussion}

\subsection{OC patterns in Arctic bivalves}

All organochlorine compounds $(\mathrm{OC})$ were found in relatively low concentrations in the four Arctic bivalve species and in the range expected for marine organisms of lower trophic levels in the Arctic (Angot, 2009; Borgå et al., 2001; Fisk et al., 2003; Hop et al., 2001; Tessmann, 2008). Their OC load was dominated by $\sum$ PCB in all species with a consistent pattern of relative abundance in terms of total $\sum \mathrm{OC}\left(\sum \mathrm{PCB}>\sum \mathrm{CHLOR}>\alpha-\mathrm{HCH}\right)$, confirming previous results for Arctic bivalves (Angot, 2009; Fisk et al., 2003; Rabieh et al., 2008; Tessmann, 2008). Both less and more hydrophobic OCs (e.g. $\alpha-\mathrm{HCH}$ and PCBs, respectively), were detected in the bivalves, which shows that partitioning from both sea water and dietary intake of suspended particulate organic matter (POM) determines their OC levels. $\alpha-\mathrm{HCH}\left(\log \mathrm{K}_{\mathrm{OW}} 3.81\right)$ has been recorded as dominant compound in sea water from Kongsfjorden and Liefdefjorden (20.2 $\mathrm{pg} \mathrm{L}^{-1}$; Hallanger et al., 2011c). This OC pattern was confirmed by analysis of sea water from the same locations in 2009 (COPOL project, unpubl. data). Accordingly, we assume that $\alpha$ $\mathrm{HCH}$ is preferentially absorbed from sea water by the bivalves instead of being taken up through their food. In contrast, the uptake of more hydrophobic OCs, such as $\sum \mathrm{PCB}\left(\log \mathrm{K}_{\mathrm{OW}} 6.2-7.0\right)$, is likely food associated (Russell et al., 1999). $\sum$ PCB was detected with up to three times higher concentrations compared to $\alpha-\mathrm{HCH}$ in suspended POM collected from Kongsfjorden and Liefdefjorden in 2009 (COPOL project, unpubl. data). Tanabe and Tatsukawa (1983) observed a more rapid vertical transport of PCBs to the sea floor with sinking particles due to the preferential absorption of PCBs on suspended POM. This implies a greater export of more hydrophobic OCs to the benthic ecosystem and could explain the dominance of $\sum \mathrm{PCB}$ in the bivalves. Furthermore, the high HCB concentration (51.1-79.0 $\mathrm{ng} \mathrm{g}^{-1} \mathrm{lw}$ ) detected only in M. truncata from Kongsfjorden contradicts previous studies (Angot, 2009; Tessmann, 2008), which have reported five times lower concentration of HCB in other bivalve species and locations in Svalbard. There is no apparent explanation for this variability in HCB levels. HCB was a dominant compound both in sea water and POM from Svalbard in 2008 (5.2 $\mathrm{pg} \mathrm{L}^{-1}$ and $0.22 \mathrm{pg} \mathrm{L}^{-1}$, respectively, Hallanger et al., 2011c) and 2009 (COPOL project, unpubl. data).

We found distinctly lower $\sum$ PCB and $\sum$ CHLOR levels $\left(\sum \mathrm{PCB}\right.$ $78.1 \mathrm{ng} \mathrm{g}^{-1} \mathrm{lw}$; $\sum$ CHLOR: $17.6 \mathrm{ng} \mathrm{g}^{-1} \mathrm{lw}$ ) than Fisk et al. (2003) for M. truncata from the North American Arctic ( $\sum$ PCB: $520 \mathrm{ng} \mathrm{g}^{-1} \mathrm{lw}$; $\sum$ CHLOR: $62.7 \mathrm{ng} \mathrm{g}^{-1} \mathrm{lw}$ ). Fisk et al. (2003) included more lower chlorinated PCBs in $\sum$ PCB, which accounted for $32 \%$ of the whole 
Table 3

Organochlorine compounds (OCs) and the sum values ( $\sum$ CHLOR and $\sum$ PCB) detected in four bivalve species from Svalbard are presented as mean concentration \pm SD and range (concentrations in $\mathrm{ng} \mathrm{g}^{-1}$ lipid weight). $\mathrm{EOM}=$ extractable organic matter. The total number of samples analyzed for the species is present in brackets in the header of the table whereas the number of samples detected above the limit of detection is shown in columns $(n)$. OCs not detected (n.d.) are indicated for the bivalve species.

\begin{tabular}{|c|c|c|c|c|c|c|c|c|c|c|c|c|}
\hline \multirow[t]{2}{*}{ OC } & \multicolumn{3}{|c|}{$\begin{array}{l}\text { Mya truncata }(n=26) \\
\mathrm{EOM}=1.04 \pm 0.12 \%\end{array}$} & \multicolumn{3}{|c|}{$\begin{array}{l}\text { Serripes groenlandicus }(n=23) \\
\mathrm{EOM}=1.13 \pm 0.34 \%\end{array}$} & \multicolumn{3}{|c|}{$\begin{array}{l}\text { Hiatella arctica }(n=15) \\
\mathrm{EOM}=1.34 \pm 0.24 \%\end{array}$} & \multicolumn{3}{|c|}{$\begin{array}{l}\text { Chlamys islandica }(n=25) \\
(\mathrm{EOM}=1.30 \pm 0.39 \%)\end{array}$} \\
\hline & $n$ & Mean \pm SD & Range & $n$ & Mean \pm SD & Range & $n$ & Mean \pm SD & Range & $n$ & Mean \pm SD & Range \\
\hline $\mathrm{HCB}$ & 6 & $61.08 \pm 1.33$ & $51.10-79.00$ & 0 & n.d. & n.d. & 0 & n.d. & n.d. & 0 & n.d. & n.d. \\
\hline$\alpha-\mathrm{HCH}$ & 20 & $9.22 \pm 3.71$ & $5.75-20.73$ & 17 & $3.85 \pm \mathbf{0 . 8 2}$ & $1.93-5.31$ & 14 & $7.20 \pm 1.41$ & $4.05-9.38$ & 16 & $3.80 \pm 0.56$ & $2.49-4.64$ \\
\hline oxy-chlordane & 11 & $4.47 \pm 3.51$ & $2.24-14.25$ & 0 & n.d. & n.d. & 9 & $1.59 \pm 0.22$ & $1.23-1.80$ & 19 & $1.53 \pm 0.35$ & $1.12-2.26$ \\
\hline trans-chlordane & 22 & $2.54 \pm 1.33$ & $0.92-4.74$ & 20 & $1.19 \pm 0.3$ & $0.61-1.82$ & 15 & $3.03 \pm 0.56$ & $2.21-3.98$ & 14 & $1.30 \pm 0.54$ & $0.66-2.25$ \\
\hline cis-chlordane & 23 & $2.29 \pm 0.93$ & $1.17-5.21$ & 19 & $0.66 \pm 0.18$ & $0.32-1.10$ & 14 & $2.70 \pm 0.43$ & $2.01-3.56$ & 23 & $1.89 \pm 0.25$ & $1.46-2.28$ \\
\hline trans-nonachlor & 24 & $2.31 \pm 0.84$ & $1.10-4.56$ & 23 & $2.01 \pm 0.4$ & $1.40-3.32$ & 15 & $3.43 \pm 0.38$ & $2.91-4.16$ & 25 & $3.19 \pm 0.58$ & $1.73-3.99$ \\
\hline cis-nonachlor & 26 & $9.44 \pm 6.77$ & $2.94-27.09$ & 23 & $5.8 \pm 3.75$ & $2.52-14.92$ & 15 & $6.60 \pm 5.40$ & $2.75-22.44$ & 25 & $6.37 \pm 3.38$ & $2.96-18.77$ \\
\hline heptachlorepoxide & 0 & n.d. & n.d. & 0 & n.d. & n.d. & 0 & n.d. & n.d. & 8 & $2.84 \pm 0.41$ & $2.40-3.46$ \\
\hline$\sum$ CHLOR & 26 & $17.64 \pm 8.83$ & $8.76-39.19$ & 23 & $9.39 \pm 4.03$ & 6.14-20.09 & 15 & $16.53 \pm 6.54$ & $10.94-34.54$ & 25 & $14.04 \pm 3.91$ & $8.37-26.49$ \\
\hline РСВ 101 & 0 & n.d. & n.d. & 0 & n.d. & n.d. & 5 & $4.70 \pm 1.51$ & $3.17-6.45$ & 13 & $6.19 \pm 2.41$ & $4.16-13.49$ \\
\hline РCB 105 & 26 & $12.07 \pm 8.34$ & $3.58-25.37$ & 16 & $8.98 \pm 5.65$ & $3.90-15.03$ & 14 & $8.02 \pm 4.29$ & $3.37-13.65$ & 24 & $7.99 \pm 3.74$ & $3.86-16.64$ \\
\hline РСВ 118 & 26 & $18.52 \pm 12.56$ & $6.08-40.51$ & 16 & $14.19 \pm 9.00$ & $5.84-36.75$ & 14 & $12.73 \pm 7.21$ & $5.39-32.16$ & 24 & $12.67 \pm 6.38$ & $4.78-25.00$ \\
\hline РCB 128 & 26 & $4.58 \pm 2.96$ & $1.40-9.99$ & 16 & $3.39 \pm 1.98$ & $1.48-8.67$ & 14 & $3.14 \pm 1.64$ & $1.28-7.38$ & 24 & $3.27 \pm 1.67$ & $1.45-7.35$ \\
\hline РСВ 138 & 26 & $17.04 \pm 10.59$ & $6.33-38.46$ & 16 & $12.50 \pm 7.11$ & $5.84-31.53$ & 14 & $11.74 \pm 5.69$ & $5.39-27.56$ & 24 & $13.3 \pm 6.23$ & $6.65-34.32$ \\
\hline PCB 141 & 25 & $1.61 \pm 0.95$ & $0.62-3.53$ & 16 & $1.13 \pm 0.67$ & $0.48-2.68$ & 14 & $1.10 \pm 0.53$ & $0.55-2.53$ & 24 & $1.09 \pm 0.55$ & $0.54-2.81$ \\
\hline РСВ 149 & 16 & $5.99 \pm 3.32$ & $2.38-11.99$ & 14 & $4.77 \pm 2.68$ & $2.01-10.72$ & 13 & $5.03 \pm 2.52$ & $2.61-12.12$ & 21 & $4.59 \pm 1.42$ & $1.58-7.74$ \\
\hline РCB 153 & 26 & $9.67 \pm 5.98$ & $3.70-20.77$ & 16 & $6.96 \pm 3.65$ & $3.64-16.14$ & 14 & $6.77 \pm 2.76$ & $4.17-14.64$ & 24 & $7.62 \pm 2.86$ & 3.99-15.92 \\
\hline PCB 156 & 26 & $2.66 \pm 1.67$ & $0.90-5.43$ & 16 & $1.95 \pm 1.17$ & $0.89-5.22$ & 13 & $1.77 \pm 0.87$ & $0.95-3.94$ & 23 & $1.79 \pm 0.87$ & $0.76-4.13$ \\
\hline РСВ 157 & 26 & $1.05 \pm 0.68$ & $0.32-2.20$ & 16 & $0.88 \pm 0.53$ & $0.33-1.98$ & 14 & $0.81 \pm 0.71$ & $0.27-2.96$ & 24 & $0.71 \pm 0.4$ & $0.28-1.59$ \\
\hline РСB 167 & 23 & $0.80 \pm 0.5$ & $0.28-1.54$ & 16 & $0.55 \pm 0.30$ & $0.29-1.37$ & 14 & $0.51 \pm 0.25$ & $0.27-1.18$ & 23 & $0.54 \pm 0.24$ & $0.26-1.17$ \\
\hline РСВ 170 & 22 & $2.14 \pm 1.02$ & $0.96-3.82$ & 12 & $1.60 \pm 0.72$ & $0.94-3.26$ & 8 & $1.40 \pm 0.42$ & $0.97-2.29$ & 18 & $1.44 \pm 0.58$ & $0.94-3.11$ \\
\hline РCB 180 & 20 & $4.23 \pm 1.74$ & $2.28-6.90$ & 8 & $3.39 \pm 0.79$ & $2.42-4.81$ & 4 & $2.83 \pm 0.89$ & $2.23-4.14$ & 10 & $3.04 \pm 1.12$ & $2.19-5.92$ \\
\hline РCB 183 & 7 & $0.84 \pm 0.18$ & $0.50-1.04$ & 0 & n.d. & n.d. & 0 & n.d. & n.d. & 6 & $0.60 \pm 0.13$ & $0.49-0.65$ \\
\hline РCB 187 & 25 & $1.11 \pm 0.56$ & $0.52-2.33$ & 15 & $0.74 \pm 0.27$ & $0.47-1.38$ & 14 & $0.85 \pm 0.26$ & $0.46-1.47$ & 24 & $0.92 \pm 0.32$ & $0.46-1.47$ \\
\hline PCB 194 & 25 & $0.42 \pm 0.28$ & $0.11-1.13$ & 16 & $0.25 \pm 0.11$ & $0.10-0.48$ & 9 & $0.16 \pm 0.05$ & $0.10-0.24$ & 17 & $0.19 \pm 0.10$ & $0.12-0.54$ \\
\hline$\sum \mathbf{P C B}$ & 26 & $78.14 \pm \mathbf{5 0 . 7}$ & 27.02-171.61 & 16 & $58.55 \pm 35.4$ & 25.57-147.97 & 14 & $\mathbf{5 5 . 3 6} \pm \mathbf{2 7 . 7 3}$ & $28.19-131.58$ & 25 & $\mathbf{5 9 . 4 7} \pm \mathbf{2 5 . 9 3}$ & $27.04-124.61$ \\
\hline
\end{tabular}

$\sum$ PCB levels. This percentage is estimated based on the PCB pattern observed before in M. truncata from Svalbard (Hop et al., 2001). A recent comparison of circumpolar OC data also showed higher $\sum \mathrm{PCB}$ in amphipods from the North American compared to the European Arctic (Borgå et al., 2005). Fisk et al. (2003) suggested that elevated PCB levels might be due to local input from point sources in the North American Arctic. In Kongsfjorden, the contribution of local point sources on PCB concentration in macrobenthos has been shown to be minimal or non-existent (Hop

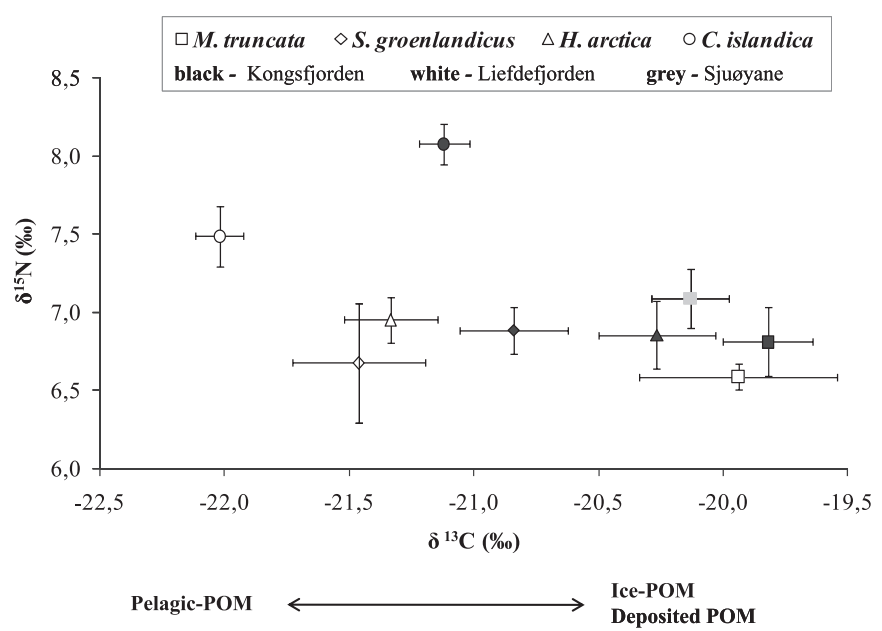

Fig. 2. Stable isotopes $\delta^{13} \mathrm{C}$ and $\delta^{15} \mathrm{~N}(\%)$ values (mean \pm SE) for Mya truncata (rectangle), Serripes groenlandicus (diamond), Hiatella arctica (triangle) and Chlamys islandica (circle) from Kongsfjorden (black), Liefdefjorden (white) and Sjuøyane (lightgrey). Lower $\delta^{13} \mathrm{C}$-values may indicate ice-associated or deposited POM, whereas higher $\delta^{13} \mathrm{C}$-values show food associated with settling, pelagic phytoplankton (Lovvorn et al., 2005; Søreide et al., 2006a). et al., 2001). The findings of similar $\sum$ CHLOR levels in amphipods from the European and North American Arctic (Borgå et al., 2005), however, are contradictive to the spatial pattern found between the study of Fisk et al. (2003) and our results. The trend of lower $\sum$ CHLOR levels in bivalves from the European than the North American Arctic (Fisk et al., 2003) has been confirmed by other studies done in Svalbard (Angot, 2009; Tessmann, 2008).

\subsection{OC differences among species}

The highest OC concentration was consistently found in M. truncata, which is contrary to a previous study (Angot, 2009) that included some of the same bivalve species from Kongsfjorden and Liefdefjorden. Serripes groenlandicus, however, had the lowest OC levels in both studies. The uptake of contaminants in suspension feeding bivalves occurs both by direct partitioning of dissolved OCs from sea water into the adipose tissue as well as through food intake of suspended POM from the ambient environment (Walker et al., 1996). Accordingly, different OC levels among the bivalves might be related to their habitat, potentially with a higher quantity of food-associated OCs for epifaunal bivalves inhabiting highcurrent habitats. In soft-bottom habitats, bivalves might be more exposed to OCs through the uptake of resuspended material and sediment, whereas the latter is a known sink for OCs such as PCB (Morrison et al., 1996). Accordingly, resuspended sediment might be an important OC source especially for soft-bottom-dwelling bivalves such as $M$. truncata and $S$. groenlandicus. Although $H$. arctica and $C$. islandica can also inhabit soft-bottom habitats, the specimens included in our study were collected from hard-bottom habitats. Since no distinct trend was found for the bivalve species collected either from soft-bottom or hard-bottom habitats in Svalbard, their habitat preferences could not explain the observed species-specific OC levels. 


\section{a}
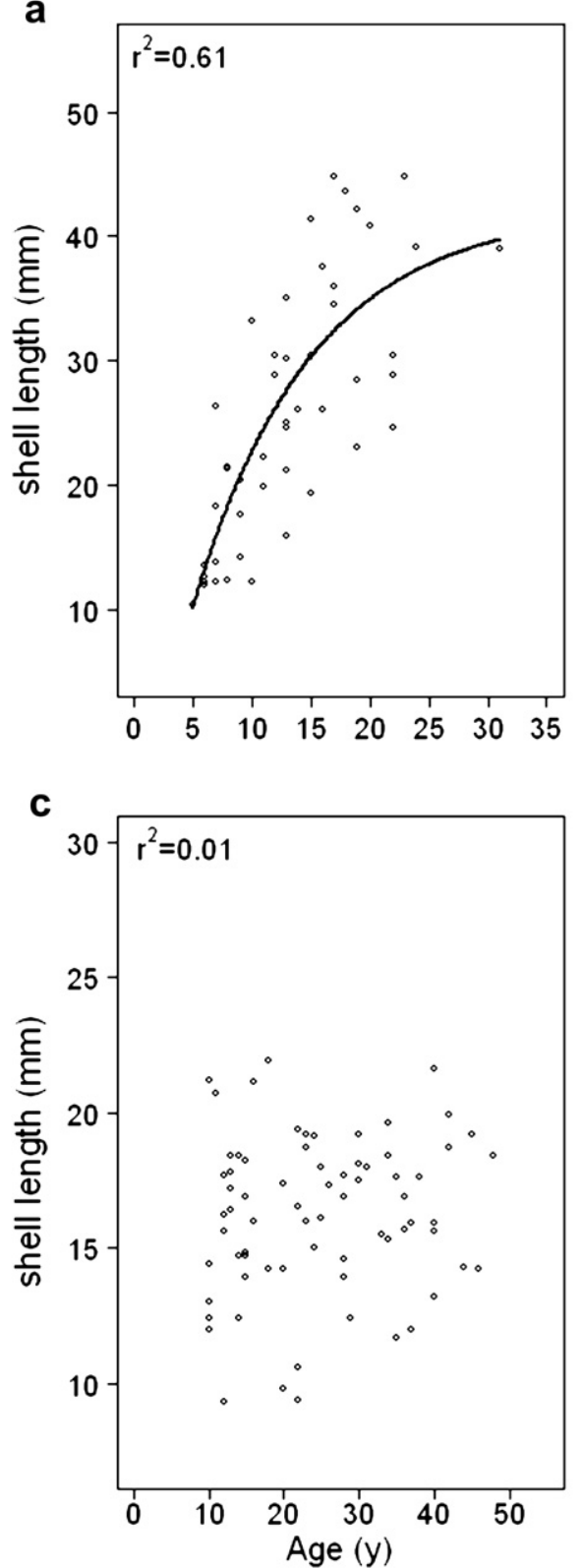

b

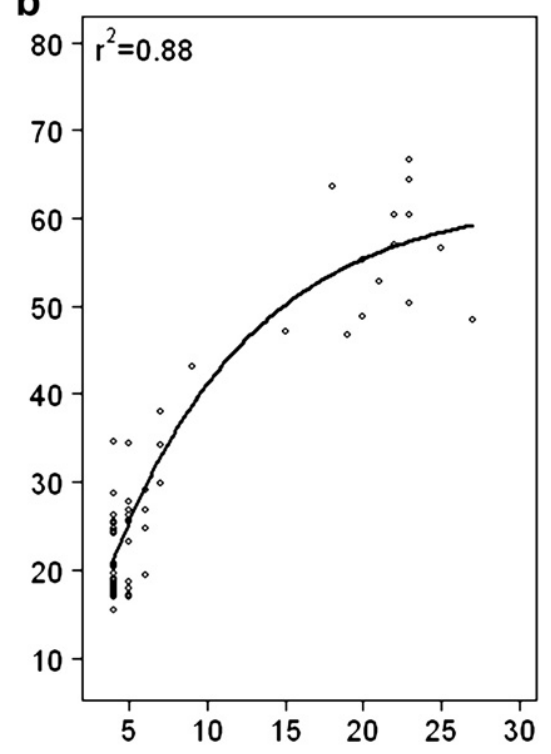

d

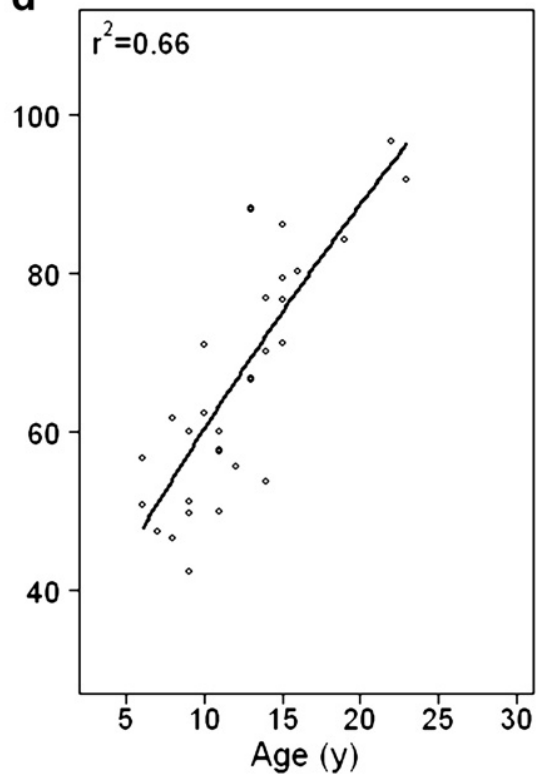

Fig. 3. Relationship between age (years) and size (shell length, $\mathrm{mm}$ ) in the bivalves Mya truncata (a), Serripes groenlandicus (b), Hiatella arctica (c) and Chlamys islandica (d) with superimposed von Bertalanffy growth curves, except for $H$. arctica, where age and size are not significantly related. The coefficient of determination $\left(r^{2}\right)$ is presented in the corresponding figures.

Stable isotope analyses revealed differences in the carbon assimilation $\left(\delta^{13} \mathrm{C}\right)$ among the bivalves, showing significantly higher $\delta^{13} \mathrm{C}$-values in $M$. truncata. Bivalves feed on particulate organic matter (POM) from the surrounding environment and difference in $\delta^{13} \mathrm{C}$ among the species may be related either to a difference in the POM type or fate. The main food source for bivalves, ice algae and phytoplankton, exhibit different $\delta^{13} \mathrm{C}$-values with higher $\delta^{13} \mathrm{C}$ in ice algae $([-20 \%]-[-19 \%])$ than phytoplankton ([-24]-[-23.8\%]; Søreide et al., 2006a), which is reflected in the isotopic values of the bivalves (McMahon et al., 2006). During the year of sampling, Kongsfjorden had very limited sea ice coverage, whereas the sea ice in Liefdefjorden retreated just 2.5 weeks before the sampling of bivalves. Accordingly, ice algae were an unlikely food source for the bivalves in Kongsfjorden. Higher $\delta^{13} \mathrm{C}$-values were observed in bivalves from Kongsfjorden $(-20.5 \%$ ) than Liefdefjorden $(-21.2 \%)$, showing that potential differences in the food type (e.g. dominance of ice algae in Liefdefjorden) cannot be seen in the $\delta^{13} \mathrm{C}$ results of the present study. The $\delta^{13} \mathrm{C}$-values are, however, in the range expected for phytoplankton ([-22.0][-19.8]) (McMahon et al., 2006; Søreide et al., 2006a), revealing phytoplankton as main food source for the bivalves. Furthermore, $\delta^{13} \mathrm{C}$ of POM have been shown to change due to degradation processes such as grazing on settling POM (Tamelander et al., $2006 \mathrm{~b}$ ) or bacterial degradation of deposited POM when it reaches the sea floor (Lehmann et al., 2002; Lovvorn et al., 2005). Accordingly, species-specific $\delta^{13} \mathrm{C}$-values in the bivalves might be related to a different supply of settling and resuspended POM in their microhabitats (epifaunal or infaunal). Tamelander et al. (2006a) observed higher $\delta^{13} \mathrm{C}$-values in resuspended sediment compared to suspended POM in the water column. This trend was 


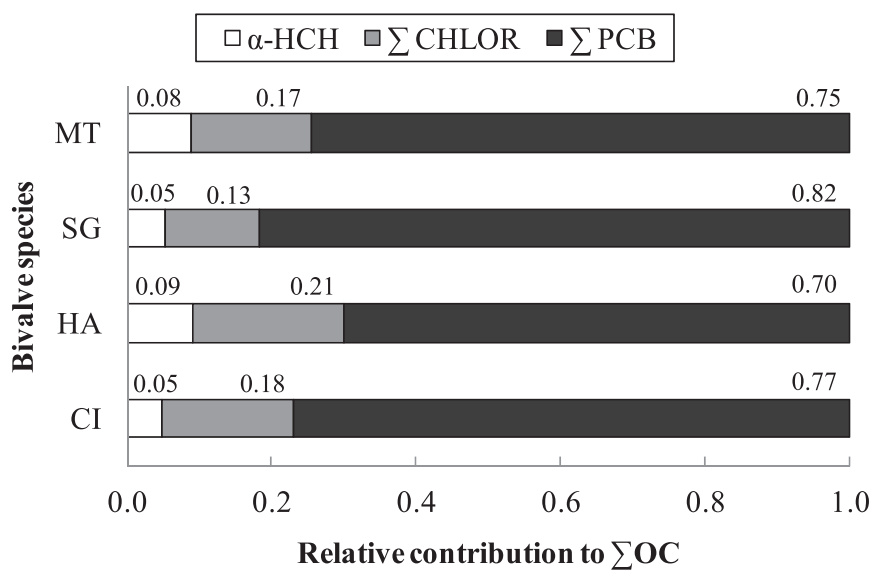

Fig. 4. Relative contribution of the mean concentration of the organochlorine groups $\left(\alpha-\mathrm{HCH}, \sum \mathrm{CHLOR}, \sum \mathrm{PCB}\right)$ to the total concentration of OCs $\left(\sum \mathrm{OC}\right)$ in Mya truncata (MT), Serripes groenlandicus (SG), Hiatella arctica (HA) and Chlamys islandica (CI) displaying the respective proportion (\%) above the bars. Samples from Kongsfjorden, Liefdefjorden and Sjuøyane are included.

also observed for POM and sediment samples collected during the same cruise (COPOL 2009), showing higher $\delta^{13} \mathrm{C}$-values in sediment samples $(<-20 \%)$ compared to settling POM $(>-20 \%)(\mathrm{COPOL}$ project, unpubl. data). Accordingly, higher $\delta^{13} \mathrm{C}$ in M. truncata can be explained by a higher intake of resuspended sediment compared to the other species. A higher sediment uptake by M. truncata might thus explain the consistently higher OC levels observed in this species. Contaminant analysis of sediment samples collected during the COPOL cruise 2009 showed PCB as dominant compound absorbed to the sediment particles and revealed resuspended sediments as another OC source for bivalves (COPOL project, unpubl. data).

Furthermore, stable isotope analyses showed also different $\delta^{15} \mathrm{~N}$-values among the species, revealing a higher trophic level for C. islandica compared to the other species. Chlamys islandica inhabits strong current habitats and can filter particles with a maximum size of $10-200 \mu \mathrm{m}$ (Vahl, 1973). Accordingly, small

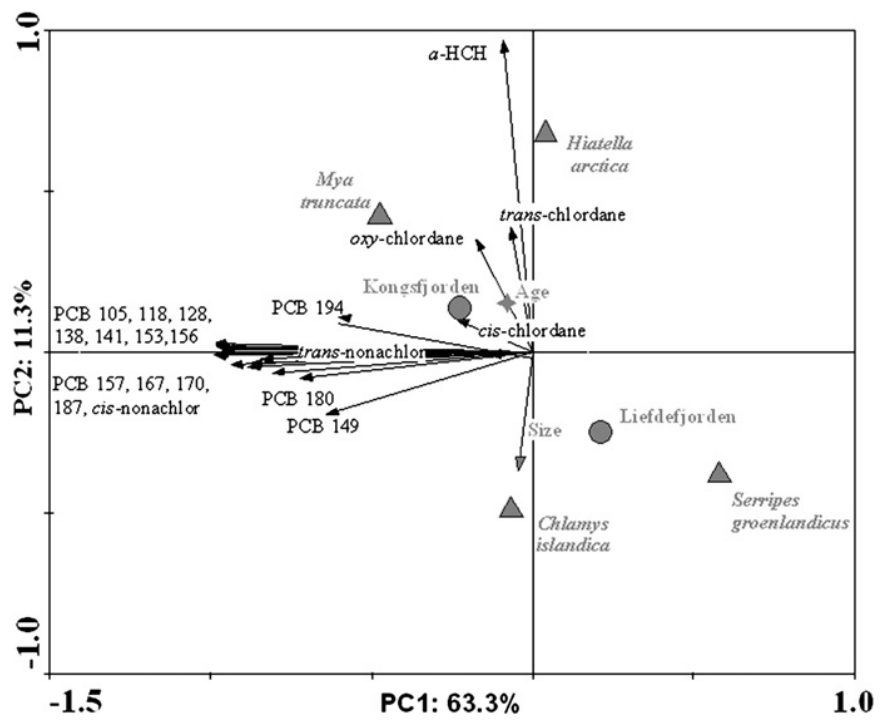

Fig. 5. Ordination diagram from principle component analysis (PCA) of logarithmically transformed organochlorine compound (OC) concentrations. Arrow indicates the individual OCs (black) and the continuous variable size (grey). Symbols represent the average sample score identified by age (star), location (circle) and bivalve species (triangle).
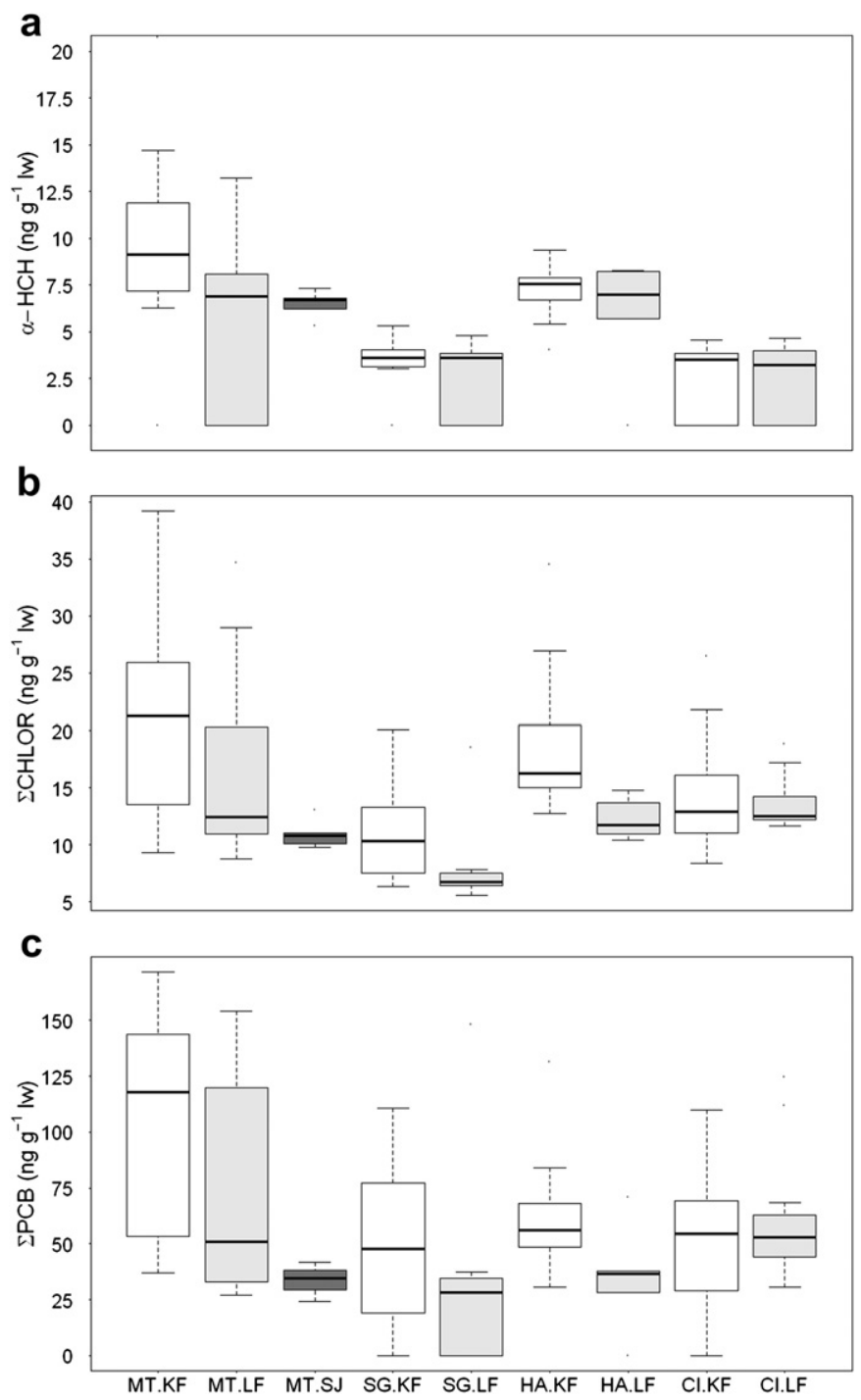

Fig. 6. Mean concentration (ng g ${ }^{-1}$ lipid weight [lw]) of $\alpha-\mathrm{HCH}(\mathrm{a}), \sum \mathrm{CHLOR}(\mathrm{b})$, and $\sum$ PCB (c) in Mya truncata (MT), Serripes groenlandicus (SG), Hiatella arctica (HA), and Chlamys islandica (CI) from Kongsfjorden (KF; white box), Liefdefjorden (LF; light-grey box) and Sjuøyane (SJ; dark-grey box). Median values (thick line), first and third quartiles (box) and range (whiskers) are depicted.

zooplankton and heterotrophic organisms of the microbial food web can be filtered in addition to phytoplankton, increasing the $\delta^{15} \mathrm{~N}$-value of the scallop. No correlation was found, however, between the stable isotope results $\left(\delta^{15} \mathrm{~N}\right.$ and $\left.\delta^{13} \mathrm{C}\right)$ and OC levels. This indicates that the bivalve food does not explain the different OC levels observed among the species in this study. This is in contrast to the findings of Fisk et al. (2003), who observed a correlation between OC levels and $\delta^{13} \mathrm{C}$-values. Despite the fact that no correlation was found between the $\delta^{13} \mathrm{C}$-values and $\mathrm{OC}$ levels, distinctly higher levels of $\mathrm{OC}$ in combination with higher $\delta^{13} \mathrm{C}$-values in $M$. truncata compared to the other species indicate a positive relationship between the bivalve's food and their OC levels. The quantity of food assimilated, however, may influence the OC levels. Petersen et al. (2003) observed slightly higher filtration rates for $M$. truncata $\left(27.4 \mathrm{ml} \mathrm{min} \mathrm{g}^{-1}\right)$ than for $H$. arctica (22.4 $\mathrm{ml} \mathrm{min}^{-1} \mathrm{~g}^{-1}$ ), which might explain the higher OC level found in M. truncata.

Size, age and lipid content did not explain differences in OC concentration, indicating the absence of OC bioaccumulation in the 
bivalves. Although size-related differences in the uptake rate of PCB have been shown for clams (Ferreira and Vale, 1998), our results did not support these findings. For organisms of at lower trophic levels, metabolism of organochlorines is assumed to play a minor role, indicated by the close relationship between the bioconcentration factor (BCF) and the log $K_{0 w}$ factor (Borgå et al., 2002a, 2002b; Porte and Albaiges, 1994). This implies that OC concentrations in these organisms are in equilibrium with the water and food. Furthermore, OC levels in organisms are strongly determined by their lipid content, i.e. higher OC levels are expected in marine invertebrates with higher lipid percentage (Fisk et al., 2003). This is also in contrary to our results, where the highest OC levels were found in $M$. truncata, which had the lowest lipid content among the four species (Table 3 ).

\subsection{Spatial trends}

Our finding of higher OC levels in Kongsfjorden compared to Liefdefjorden and also Sjuøyane for M. truncata confirms previous studies of bivalves (Angot, 2009) and zooplankton (Hallanger et al., 2011c). OCs are mostly imported by atmospheric long-range transport (Wania and Mackay, 1993) but also by oceanic currents and Arctic sea ice (Pfirman et al., 1995). Most likely, the observed differences are related to the different oceanographic regimes in Kongsfjorden and Liefdefjorden-Sjuøyane, respectively. The latter sites are dominated by Arctic water masses, where the former is strongly influenced by Atlantic water masses advected from the West Spitsbergen Current into the fjord (Cottier et al., 2005) and thereby by OCs of North Atlantic origin. Hallanger et al. (2011c), however, did not find a clear difference in the OC levels of the dissolved water phase between Kongsfjorden and Liefdefjorden. They proposed differences in sea ice cover, onset of snow or glacial melt and different algal bloom stages as causes for spatial OC differences in zooplankton. Phytoplankton dynamics may also explain the OC pattern found in our study, given that higher primary production produces greater fraction of particle associated OCs in surface waters (Hargrave et al., 2000) and enhanced vertical flux of OCs to the benthic community (Tanabe and Tatsukawa, 1983). The ice-free summer season is distinctly shorter in Liefdefjorden than in Kongsfjorden, and so is the primary production period and subsequent vertical flux of POM-associated OCs. Significantly higher $\delta^{13} \mathrm{C}$ in bivalves from Kongsfjorden $(-20.5 \%)$ than Liefdefjorden $(-21.2 \%)$ reveal a more ${ }^{13} \mathrm{C}$ enriched food source in Kongsfjorden, which was confirmed by higher $\delta^{13} \mathrm{C}$ values measured in POM from Kongsfjorden than Liefdefjorden (COPOL project, unpubl. data). Differences in $\delta^{13} \mathrm{C}$ levels in POM can indicate different stages of phytoplankton blooms (Tamelander et al., 2009), implying that higher $\delta^{13} \mathrm{C}$-values measured in Kongsfjorden reflect the earlier spring bloom in this fjord. Furthermore, higher ambient temperature leads to enhanced metabolism in poikilotherm animals (Clarke, 1998) and thus to higher filtration and consumption rates (see Petersen et al., 2003 for data on $M$. truncata and $H$. arctica) which implies higher OC uptake for bivalves inhabiting warmer (Kongsfjorden) compared to colder water regimes (Liefdefjorden).

In conclusion, this study revealed that OC levels in bivalves varied in relation to species and geographic location, but not with to bivalve size and age. Species-specific differences, however, highlight that OC assessment of Arctic macro-benthos should include different taxonomic groups and species in order to obtain an unbiased picture of contaminant levels. Although variation in food source and quantity could partly explain the OC pattern found, additional investigations are needed in order to understand the OC dynamics in bivalves. Future studies should include OC analyses of distinct food sources and quantify food intake. Although the spatial
OC differences found support previous findings for Svalbard, further investigations of marine food webs in the Arctic are required in order to understand the factors and mechanisms that drive this spatial difference.

\section{Acknowledgments}

The authors would like to thank Ingeborg Gammelsæter Hallanger and Malin Daase for their help with the data analysis and handling of $R$ as well as Kjetil Sagerup for his valuable comments on the final draft of the article. Furthermore we thank the diving team for the sample collection and their support in the field. Funding for this project was provided by the Norwegian Research Council via the International Polar Year (IPY) project: Contaminants in Polar Regions (COPOL, 176073/S30).

\section{Appendix. Supplementary data}

Supplementary data associated with this article can be found, in the online version, at doi:10.1016/j.envpol.2011.10.018.

\section{References}

AMAP, 1998. AMAP Assessment Report: Arctic Pollution Issues. Arctic Monitoring and Assessment Programme (AMAP), Oslo, Norway, xii+859 pp.

AMAP, 2004. AMAP Assessment 2002: Persistent Organic Pollutants in the Arctic. Arctic Monitoring and Assessment Programme (AMAP), Oslo, Norway, xvi+310 pp.

Ambrose Jr., W.G., Carroll, M.L., Greenacre, M., Thorrold, S.R., McMahon, K.W., 2006. Variation in Serripes groenlandicus (Bivalvia) growth in a Norwegian high-Arctic fjord: evidence for local- and large-scale climatic forcing. Global Change Biology $12,1595-1607$.

Angot, H., 2009. Spatial differences in organochlorine pesticide concentrations in the benthic community in Svalbard. Master thesis. Nationale Graduate School of Chemistry (ENSCM), Montpellier, France.

Borgå, K., Gabrielsen, G.W., Skaare, J.U., 2001. Biomagnification of organochlorines along a Barents Sea food chain. Environmental Pollution 113, 187-198.

Borgå, K., Gabrielsen, G.W., Skaare, J.U., 2002a. Differences in contamination load between pelagic and sympagic invertebrates in the Arctic marginal ice zone: influence of habitat, diet and geography. Marine Ecology Progress Series 235, 157-169.

Borgå, K., Poltermann, M., Polder, A., Pavlova, O., Gulliksen, B., Gabrielsen, G.W., Skaare, J.U., 2002b. Influence of diet and sea ice drift on organochlorine bioaccumulation in Arctic ice-associated amphipods. Environmental Pollution 117, 47-60.

Borgå, K., Fisk, A.T., Hoekstra, P.F., Muir, D.C.G., 2004. Biological and chemical factors of importance in the bioaccumulation and trophic transfer of persistent organochlorine contaminants in Arctic marine food webs. Environmental Toxicology and Chemistry 23, 2367-2385.

Borgå, K., Gabrielsen, G.W., Skaare, J.U., Kleivane, L., Norstrom, R.J., Fisk, A.T., 2005. Why do organochlorine differences between arctic regions vary among trophic levels? Environmental Science \& Technology 39, 4343-4352.

Brey, T., 2001. Population Dynamics in Benthic Invertebrates. A Virtual Handbook. Version 01.2 URL. http://www.thomas-brey.de/science/virtualhandbook (last accessed: 12.04.11.)

Bright, D.A., Dushenko, W.T., Grundy, S.L., Reimer, K.J., 1995. Effects of local and distant contaminant sources: polychlorinated biphenyls and other organochlorines in bottom-dwelling animals from an Arctic estuary. Science of the Total Environment 160-161, 265-283.

Bustnes, J.O., Gabrielsen, G.W., Verreault, J., 2010. Climate variability and temporal trends of persistent organic pollutants in the Arctic: a study of Glaucous gulls. Environmental Science \& Technology 44, 3155-3161.

Clarke, A., 1998. Temperature and energetics: an introduction to cold ocean physiology. In: Pörtner, H.O., Playle, R.C. (Eds.), Cold Ocean Physiology. Cambridge University Press, Cambridge, UK, pp. 3-30.

Cottier, F., Tverberg, V., Inall, M., Svendsen, H., Nilsen, F., Griffiths, C., 2005. Water mass modification in an Arctic fjord through cross-shelf exchange: the seasonal hydrography of Kongsfjorden, Svalbard. Journal of Geophysical ResearchOceans 110, C12005. doi:10.1028/2004JC002757.

Doidge, D.W., Kaminski, G., Messher, C., 1993. Blue mussels (Mytilus edulis) in Nunavik: Distribution, Demography and Commercial Potential, Report to Fisheries and Aquaculture Testing and Experimentation Program of Department of Fisheries and Oceans. $31 \mathrm{pp}$.

Evenset, A., Christensen, G.N., 2009. PCB i bosettinger på Svalbard-et problem for dyrelivet i havet?, Report no. 4352-1. 84 pp.

Ferreira, A.M., Vale, C., 1998. РCB accumulation and alterations of lipids in two length classes of the oyster Crassostrea angulata and of the clam Ruditapes decussatus. Marine Environmental Research 45, 259-268. 
Fisk, A.T., Hoekstra, P.F., Gagnon, J.M., Duffe, J., Norstrom, R.J., Hobson, K.A. Kwan, M., Muir, D.C.G., 2003. Influence of habitat, trophic ecology and lipids on, and spatial trends of, organochlorine contaminants in Arctic marine invertebrates. Marine Ecology Progress Series 262, 201-214.

Hallanger, I.G., Ruus, A., Herzke, D., Warner, N.A., Evenset, A., Heimstad, E.S. Gabrielsen, G.W., Borgå, K., 2011a. Influence of season, location, and feeding strategy on bioaccumulation of halogenated organic contaminants in Arctic marine zooplankton. Environmental Toxicology and Chemistry 30, 77-87.

Hallanger, I.G., Warner, N.A., Ruus, A., Evenset, A., Christensen, G., Herzke, D. Gabrielsen, G.W., Borgå, K., 2011b. Seasonality in contaminant accumulation in Arctic marine pelagic food webs using trophic magnification factor as a measure of bioaccumulation. Environmental Toxicology and Chemistry 30 , 1026-1035.

Hallanger, I.G., Ruus, A., Warner, N.A., Herzke, D., Evenset, A., Schøzen, M. Gabrielsen, G.W., Borgå, K., 2011c. Differences between Arctic and Atlantic fjord systems on bio-accumulation of persistent organic pollutants in zooplankton from Svalbard. Science of the Total Environment 409, 2783-2795.

Hargrave, B.T., Phillips, G.A., Vass, W.P., Bruecker, P., Welch, H.E., Siferd, T.D., 2000. Seasonality in bioaccumulation of organochlorines in lower trophic level Arctic marine biota. Environmental Science \& Technology 34, 980-987.

Henriksen, E.O., Wiig, O., Skaare, J.U., Gabrielsen, G.W., Derocher, A.E., 2001. Monitoring PCBs in polar bears: lessons learned from Svalbard. Journal of Environmental Monitoring 3, 493-498.

Herzke, D., Nygård, T., Berger, U., Huber, S., Rov, N., 2009. Perfluorinated and other persistent halogenated organic compounds in European shag (Phalacrocorax aristotelis) and common eider (Somateria mollissima) from Norway: a suburban to remote pollutant gradient. Science of the Total Environment 408, 340-348.

Hop, H., Sagerup, K., Schlabach, M., Gabrielsen, G.W., 2001. Persistent Organic Pollutants in Marine Macro-benthos Near Urban Settlements in Svalbard Longyearbyen, Pyramiden, Barentsburg, and Ny-Ålesund, Norwegian Polar Institute Report no 8. 43 pp.

Hop, H., Pearson, T., Hegseth, E.N., Kovacs, K.M., Wiencke, C., Kwasniewski, S. Eiane, K., Mehlum, F., Gulliksen, B., Wlodarska-Kowalzuk, M., Lydersen, C., Weslawski, J.M., Cochrane, S., Gabrielsen, G.W., Leakey, R.J.G., Lønne, O.J., Zajaczkowski, M., Falk-Petersen, S., Kendall, M., Wängberg, S.-Å., Bischof, K., Voronkov, A.Y., Kovaltchouk, N.A., Wiktor, J., Poltermann, M., di Prisco, G. Papucci, C., Gerland, S., 2002. The marine ecosystem of Kongsfjorden, Svalbard. Polar Research 21, 167-208.

IPCC, 2007. Climate Change 2007:The Physical Science Basis. Cambridge University Press, Cambridge, UK.

Johannessen, O.H., 1973. Age determination in Chlamys islandica (O.F.Müller). Astarte 6, 15-20.

Kjolholt, J., Hansen, M.M., 1986. PCBs in scallops and sediments from North Greenland. Marine Pollution Bulletin 17, 432-434.

Kuzyk, Z.A., Stow, J.P., Burgess, N.M., Solomon, S.M., Reimer, K.J., 2005. PCBs in sediments and the coastal food web near a local contaminant source in Saglek Bay, Labrador. Science of the Total Environment 351, 264-284.

Lehmann, M.F., Bernasconi, S.M., Barbieri, A., McKenzie, J.A., 2002. Preservation of organic matter and alteration of its carbon and nitrogen isotope composition during simulated and in situ early sedimentary diagenesis. Geochimica et Cosmochimica Acta 66, 3573-3584.

Lovvorn, J.R., Cooper, L.W., Brooks, M.L., De Ruyck, C.C., Bump, J.K., Grebmeier, J.M., 2005. Organic matter pathways to zooplankton and benthos under pack ice in late winter and open water in late summer in the north-central Bering Sea. Marine Ecology Progress Series 291, 135-150.

Macdonald, R.W., Mackay, D., Li, Y.F., Hickie, B., 2003. How will global climate change affect risks from long-range transport of persistent organic pollutants? Human and Ecological Risk Assessment 9, 643-660.

McMahon, K.W., Ambrose Jr., W.G., Johnson, B.J., Sun, M.Y., Lopez, G.R., Clough, L.M., Carroll, M.L., 2006. Benthic community response to ice algae and phytoplankton in Ny Ålesund, Svalbard. Marine Ecology Progress Series 310, 1-14.

Morrison, H.A., Gobas, F.A.P.C., Lazar, R., Haffner, G.D., 1996. Development and verification of a bioaccumulation model for organic contaminants in benthic invertebrates. Environmental Science \& Technology 30, 3377-3384.
Petersen, J.K., Sejr, M.K., Larsen, J.E.N., 2003. Clearance rates in the Arctic bivalves Hiatella arctica and Mya sp. Polar Biology 26, 334-341.

Pfirman, S.L., Eicken, H., Bauch, D., Weeks, W.F., 1995. The potential transport of pollutants by Arctic sea-ice. Science of the Total Environment 159, 129-146.

Porte, C., Albaiges, J., 1994. Bioaccumulation patterns of hydrocarbons and polychlorinated-biphenyls in bivalves, crustaceans, and fishes. Archives of Environmental Contamination and Toxicology 26, 273-281.

Program U.N.E, 2001. Final Act of the Conference of Plenipotentiaries on the Stockholm Convention on Persistent Organic Pollutants Geneva, Switzerland.

Rabieh, S., Jónsdóttir, I., Ragnarsdóttir, P., Gunnlaugsdóttir, H., 2008. Monitoring of the Marine Biosphere around Iceland 2006 and 2007. University of Iceland, Reykjavik, Matis project Report no 21-08. 66 pp.

Renaud, P.E., Tessmann, M., Evenset, A., Christensen, G.N., 2011. Benthic food-web structure of an Arctic fjord (Kongsfjord, Svalbard). Marine Biology Research 7, $13-26$.

Rudels, B., Meyer, R., Fahrbach, E., Ivanov, V.V., Østerhus, S., Quadfasel, D. Schauer, U., Tverberg, V., Woodgate, R.A., 2000. Water mass distribution in Fram Strait and over the Yermak Plateau in summer 1997. Annales GeophysicaeAtmospheres Hydrospheres and Space Sciences 18, 687-705.

Russell, R.W., Gobas, F., Haffner, G.D., 1999. Role of chemical and ecological factors in trophic transfer of organic chemicals in aquatic food webs. Environmental Toxicology and Chemistry 18, 1250-1257.

Schöne, B.R., Fiebig, J., Pfeiffer, M., Gless, R., Hickson, J., Johnson, A.-L.-A., Dreyer, W., Oschmann, W., 2005. Climate records from a bivalved Methuselah (Arctica islandica, Mollusca; Iceland). Palaeogeography Palaeoclimatology Palaeoecology 228, 130-148

Søreide, J.E., Hop, H., Carroll, M.L., Falk-Petersen, S., Hegseth, E.N., 2006a. Seasonal food web structures and sympagic-pelagic coupling in the European Arctic revealed by stable isotopes and a two-source food web model. Progress in Oceanography 71, 59-87.

Søreide, J.E., Tamelander, T., Hop, H., Hobson, K.A., Johansen, I., 2006b. Sample preparation effects on stable $\mathrm{C}$ and $\mathrm{N}$ isotope values: a comparison of methods in Arctic marine food web studies. Marine Ecology Progress Series 328, 17-28.

Svendsen, H., Beszczynska-Møller, A., Hagen, J.O., Lefauconnier, B., Tverberg, V., Gerland, S., Ørbæk, J.B., Bischof, K., Papucci, C., Zajaczkowski, M., Azzolini, R, Bruland, O., Wiencke, C., Winther, J.G., Dallmann, W., 2002. The physical environment of Kongsfjorden-Krossfjorden, an Arctic fjord system in Svalbard. Polar Research 21, 133-166.

Tamelander, T., Renaud, P.E., Hop, H., Carroll, M.L., Ambrose Jr., W.G., Hobson, K.A., 2006a. Trophic relationships and pelagic-benthic coupling during summer in the Barents Sea Marginal Ice Zone, revealed by stable carbon and nitrogen isotope measurements. Marine Ecology Progress Series 310, 33-46.

Tamelander, T., Søreide, J.E., Hop, H., Carroll, M.L., 2006b. Fractionation of stable isotopes in the Arctic marine copepod Calanus glacialis: effects on the isotopic composition of marine particulate organic matter. Journal of Experimental Marine Biology and Ecology 333, 231-240.

Tamelander, T., Kivimäe, C., Bellerby, R.G.J., Renaud, P.E., Kristiansen, S., 2009. Baseline variations in stable isotope values in an Arctic marine ecosystem: effects of carbon and nitrogen uptake by phytoplankton. Hydrobiologia 630, 63-73.

Tanabe, S., Tatsukawa, R., 1983. Vertical transport and residence time of chlorinated hydrocarbons in the open ocean water column. Journal of the Oceanographical Society of Japan 39, 53-62.

Tessmann, M., 2008. Trophic transfer of persistent organic pollutants in the benthic food web of Kongsfjorden, Spitzbergen. Master thesis. Christian-Albrecht-Universität zu Kiel, Germany.

Vahl, O., 1973. Efficiency of particle retention in Chlamys islandia (O.F. Müller) Astarte 6, 21-25.

von Bertalanffy, L., 1957. Quantitative laws in metabolism and growth. The Quarterly Review of Biology 32, 217-231.

Walker, C.H., Hopkin, S.P., Sibly, R.M., Peakall, D.B., 1996. Principles of Ecotoxicology. CRC Taylor \& Francis, London, UK.

Wania, F., Mackay, D., 1993. Global fractionation and cold condensation of low volatility organochlorine compounds in polar regions. AMBIO 22, 10-18. 